\title{
MODERN EDUCATIONAL AND PEDAGOGICAL STRATEGIES AND TECHNOLOGIES FOR THE FORMATION OF ASSERTIVE BEHAVIOR OF STUDENTS IN PROFESSIONAL DEVELOPMENT
}

\section{Marchuk L. M.}

\section{INTRODUCTION}

Today, more than ever, our state is interested in training highly qualified personnel. To this end, new educational standards are being introduced and the foundations for the training of competitive specialists are being laid. One of the key tasks of modernization of modern education is the development of a person in the profession, taking into account their own ideas about themselves and the possibility of successful implementation in a particular field of work. This task acquires special significance in the period of actualization of the problem of professional self-determination - the period of choosing a profession and professional training. Today's professions, especially the professions of the category "person - person", are associated with such qualities as competence, ability to continuous professional growth, where the process of professional activity takes place in the mode of intensive social communication and requires adequate self-control. Domestic researchers studying this problem have come to the conclusion that "professional qualities are personality traits, the totality of which are potential or actual abilities for this activity, and their weakening leads to persistent erroneous actions in vocational training and further to reduce the effectiveness of a certain professional activity". In this process, a set of qualities is extremely important, which received such a name in modern psychological science as assertiveness.

The formation of assertive behavior leads to the activation of positive psychological qualities, which is certainly very important in the process of personality development. Assertive behavior on the one hand ensures the success of the individual, and on the other - eliminates such destructive psychological manifestations as aggression, passivity, propensity to depression and so on. That is why the problem of forming assertive behavior in the process of professional development of students 
of domestic higher educational institutions is an important not only scientific problem, but also a practical applied system of stimulating personal self-development.

Assertiveness in further professional activity is a means of achieving mutual understanding and harmony in the team, and such qualities as emotional stability, self-confidence and optimal level of self-control, allow to ensure successful professional growth and adequate psychological climate in both professional and personal relationships.

At the same time, the modern system of higher education requires the personification of the educational process, a personal-individualized approach to the formation of positive qualities of students. All this, given the lack of research on this scientific issue, undoubtedly actualizes the formation of assertive behavior of students through the use of modern techniques.

\section{Assertive behavior of student youth in professional development}

In social psychology, the phenomenon of "personality formation" is defined as the acquisition by a person of new features and forms in the process of development; approaching a certain state; the result of development. The decisive role in the formation of personality is played by activity. E. Zeyer defines formation as a personality-creating function, which inevitably leads to the allocation in a continuous process of formation of personality period associated with the choice, preparation for performance and performance by an adult of one type of activity professional. This transformation, according to scientists, is accompanied by a number of factors, including: socio-economic relations, social situation, the position of the individual occupy a significant part of his life $^{1}$. The closest, though not identical to the concept of "formation" are "development" and "formation", which are characterized by the acquisition of the subject of integrity, a certain completeness of professional activity.

It is argued that true professional development is possible only if the formation of a person capable of recognizing the current state of development of their abilities, aware of the need for change and transformation of the inner world, find new reserves of self-realization in work and more. According to S. Maksymenko, this makes it possible to

1 Зеер Э.Ф. Психология профессионального образования : учебное пособие. Воронеж : Изд-во НПО «Модек», 2003. 480 с. 
reveal the essence of professional development in its genetic connection with the previous stages of development of a specialist as a graduate.

At the stage of formation of professional intentions the student must obtain the necessary knowledge about the social significance of the future profession, possible forms and methods of training, conditions of activity, requirements for the specialist of the chosen profession. Here an important role should be given to the dynamic properties of the individual, such as: emotional stability, mobility, the ability to quickly navigate in a problematic situation - assertiveness. The student develops initial professional knowledge and skills, ways to solve educational and professional problems. In a new social status of development, students seek to identify the most important goals, ideals, meaning of life, respectively, forming certain behavioral strategies for the implementation of plans. It is an independent social group, which is a set of individuals united by common interests that are in interaction with each other. Assist each other in achieving personal goals. Characteristic of student youth is personal independence, the value of freedom in decision-making, the prestige of education.

The students are a period of conscious formation of personality on a psychological and intellectual level in particular, so this age category is one of those that is a defining period of human development in general. This age is the main period of socialization and maturity, at the same time it is characterized by the maximum effect of the external environment and this effect is a conscious result of independent interaction of young people with the outside world. At this age, the individual forms its main conscious stereotypes, which, along with the acquisition of knowledge in higher education, form a personalpsychological structure based on intellectual self-awareness of the social significance of the individual. This age is characterized by the active development of moral and aesthetic feelings, strengthening of conscious motives of behavior, purposefulness, determination and persistence, independence and initiative, the ability to control oneself. Interest in moral problems increases (goals and meaning of life, duty and responsibility, love and friendship, etc.), there is an active formation of individual style of activity. At the same time, as sociological research shows, modern youth often do not know how to navigate in social situations, determine the personal characteristics and emotional states of others, choose adequate behaviors and implement them in the process of interaction; demonstrate uncompromising actions, and in some cases the inability to effectively and adequately communicate with others. The 
lack of ability of a person to put forward and implement their own goals, needs, desires, aspirations, interests and feelings leads to an increased level of dissatisfaction with life, inability to plan their own future, the emergence of social fear. In this sense, the idea of assertiveness involves the development of a certain quality of behavior in the individual, so it can have spontaneous reactions, reasonable expression of emotions, the ability to speak directly about their desires and requirements, able to express their own point of view, not afraid to object., when any argument is superfluous or inappropriate; to have tactics of satisfying one's own demands and refusing to respond to inadmissible aspirations in such a way that the rights of others are not violated. Therefore, assertiveness, on the one hand, is of great importance for students for personal and professional development, and on the other - provides adequate adaptation in the socio-cultural and new educational environment, and active resistance to adaptogenic influences, protection from them or their elimination ${ }^{2}$.

Assertiveness is a necessary condition for the existence of the individual as a subject of activity, able to independently choose the direction of professional development, life goals. The ability to assertive behavior of the individual develops on the basis of introspection is expressed in the need for self-knowledge; analysis of the goals set by a person in an effort to take the desired place; the need for self-analysis of one's own choice, which is carried out on the basis of certain personal claims; the need for self-assessment of how other people evaluate it; in the ability to self-observation, self-knowledge of their own qualities, actions, performance and possible subjective difficulties in their implementation, (representatives of the family and people, professional standards and moral ideal) based on the assessment of these qualities by a mentor, personal psychologist, priest, other trustee; in the ability to reflect, analyze their actions and deeds, correct understanding of themselves, their inclinations and abilities, character traits, analysis of properly developed real goals, action plans (taking into account the views of others); in the ability to control themselves, their thoughts, actions, deeds, realizing that it depends on the success of behavior and activities (listen to assess the results of their own activities by others), the

2 Дріга Т.Г. Психологічні особливості формування асертивності студентів вищого навчального закладу. Теоретичні і прикладні проблеми психології. 2012. № 3 (29). С. 118-124. 
ability to build their life goals based on their own characteristics, properties, capabilities; self-esteem, self-respect, self-belief.

The scientists state that assertiveness is a skill that can be acquired. According to V.A. Semichenko, assertiveness is manifested in the fact that an assertive person has a clear purpose and is able to control their actions and deeds, not susceptible to rapid manipulation and emotional pressure from others. Assertiveness does not mean ignoring other people's emotions and aspirations. This is the ability to realize certain goals despite the negative pressures from the environment, rational care for their own interests while taking into account the interests of others. Thus, assertiveness develops in society, in contact with others, other people. The inclusion of the individual in different conditions of socialization allows him to develop his own style of interaction ${ }^{3}$. Constructive interaction in this age period carries an existential meaning, in which the other person is seen as a manifestation of life, a manifestation of existence, which, in turn, has its own expressiveness, not identical to anything. Understanding and experiencing the value of another person as a condition of creation, makes a person of adolescence sensitive to the perception of their own experiences and the experiences of others ${ }^{4}$. The ability to deeper, existential experiences at this age allows us to speak of the emergence of an assertive position, which is based on a conscious rejection of violent methods of influence on others. Thus, we can say that in adolescence there is an understanding and awareness of oneself and others. In this case, a positive attitude towards themselves and others, allows individuals to take a position of cooperation ${ }^{5}$.

A distinctive feature of assertive behavior is an adequate assessment of one's responsibility. In insecure behavior, a shy person takes responsibility, an aggressive person transfers it to others. Self-doubt is most pronounced in communication situations. V.G. Romek emphasizes the following manifestations of insecurity: fear of being neglected, low self-esteem, irrational beliefs, excessive desire to "adhere to decency", lack of skills to express feelings ${ }^{6}$. Thus, responsibility makes behavior constructive, allows you to build different strategies, while choosing different ways to achieve the goal and find the best. The prerequisites for

${ }^{3}$ Семиченко В.А. Психологія особистості. Київ, 2001. 427 с.

${ }_{5}^{4}$ Абрамова Г.С. Возрастная психология. Екатеринбург, 1999. 672 с.

5 Борисова А.А. Проницательность как проблема психологии общения. Вопросы психологии. 1990. № 4. С. 117-130.

${ }^{6}$ Шамиева В.А. Ассертивность в стуктуре личности субъекта адаптации : автореф. дисс. ... канд. психол. Наук : 19.00.01. Хабаровск, 2009. 27 с. 
such behavior are cognitive and personal characteristics of personality development, which allow a young person to become not only more responsible, but also consciously treat themselves and others ${ }^{7}$.

It is the manifestation of assertiveness as a personality trait that helps student youth to take a certain value position, and based on this position, to achieve their goals; involves the formation in a person of a certain quality of behavior, through which he can have spontaneous reactions, reasonable expression of emotions, the ability to speak directly about their desires and requirements, express their own point of view, not afraid to object, using arguments, insist on their own in situations where which argument is superfluous, so as not to violate the rights of others. In this case, the assertive behavior of students, in our opinion, is the result of overcoming personal and psychological contradictions between active and passive life position on the one hand, and aggressive and peaceful reaction to external influences - on the other. The result of overcoming such contradictions is the formation of an adequate response in acute social situations and awareness of personal responsibility in the process of socially significant actions of the student. This requires confident and decisive behavior based on adequate and balanced decisions and responsibility for one's own actions. Thus, increasing assertiveness increases the status of the individual and helps to determine the strategy to achieve the goal.

During the student period the most favorable conditions for the development of assertiveness are created. The ability to be assertive implies the ability to reflect, emotional stability, independence in decision-making and actions, and so on. Thanks to the more developed principles of assertive behavior, positive experience is accumulated to overcome life problems, make responsible decisions and perform motivated actions in real life situations. In the development of a holistic, resistant to aggressive and manipulative influences of the individual socio-pedagogical aspect of assertiveness is based on mutual recognition of rights. Qualitative interaction of the teacher as a carrier of assertiveness and the student as a subject of the educational process is determined by the role of the teacher, which contributes to the allocation of the assertive potential of the student ${ }^{8}$. A person who is able and

7 Лисовский В.Т. Советское студенчество: Социологические очерки. Москва, 1990. 304 с.

8 Пилипенко О.І. Удосконалення педагогічної соціалізації на основі асертивного підходу. Педагогічна теорія і практика. 2010. Вип. 3. С. 34-40. 
willing to defend his right to belief, is able to realize their own rights, but at the same time recognizes the rights and beliefs of another person - is a person of an ideal future. Note that the desired model of the future and man in it will not come if you do not educate modern youth on the basis of the ideology of assertiveness.

The idea of the student's assertive personality presupposes the presence of a specified quality of behavior, due to which there is a possession of spontaneous reactions, reasonable expression of emotions, the ability to speak directly about their desires and requirements, express their own point of view, not be afraid to deny, insist is redundant or inappropriate; to have tactics of satisfying one's own demands and refusing to respond to inadmissible aspirations in such a way that the rights of others are not violated. Accordingly, assertive behavior in the learning process, on the one hand, gains experience of personal and professional development, and on the other - provides adequate adaptation to the new educational and sociocultural environment and active counteraction to adaptogenic influences, protection from them or their elimination. This version of gaining experience depends on the mastery of students in the learning process of a set of social roles, the complexity of the formation of both personal and professional abilities, among which, assertive behavior, according to L. Podoliak, acquires special significance?

In our version, the social role is defined as a set of normatively determined social characteristics, expectations and obligations in combination with a specific social position. The student can have many roles. The effectiveness of the role, its creative color, individualization depend on the existing value system of the individual. Awareness of the social demand for a certain scenario of a social role without a socially oriented value basis leads to the fact that the individual only imitates the proper performance of the social role, without internalizing it in their inner world. The latter is based on the humanistic (for which the goals, interests and needs of other people acquire the leading value for the future psychologist), existential (for which the predominant value is the desire for self-analysis, self-improvement and self-realization); pragmatic (focuses the individual on planning professional activities and achieving success in it); egocentric (in which goals, interests, needs of

9 Подоляк Н.М. Психологічні особливості асертивності. Наука $i$ освіта. 2010. № 9. С. 108-111. 
the individual, which have a predominantly selfish nature, occupy the most important place in the hierarchy of values) paradigm.

Ideally, it can be achieved no matter how confident the student feels in a developmental learning environment. The latter depends on the locus of control, which reflects faith in oneself and in the ability to influence the course of events in the acquisition of professional qualities, knowledge, skills and experience; control and reflect on them. These qualities help to differentiate future professionals into external (who see the cause of everything that happens to them in external circumstances) and interns (who are able to take responsibility for everything that happens in their lives; self-confident; and those who rely only on on itself). Interns are more natural, independent and self-sufficient, have strong-willed qualities and confident behavioral actions.

Thus, a distinctive feature of the student's assertive behavior in the learning process is the formation of an adequate assessment of selfconfidence. Accordingly, a student who behaves assertively in a given situation does not blame others for his own troubles, and in case of luck - convinces himself of success, which is the result of forming in students in the process of educational interaction such an important quality as "social position". Social position in the process of mastering the profession is manifested in purposefulness, determination, perseverance, independence, initiative, ability to control themselves; confidence. According to I. Lebedeva, their essence is manifested in the stability of behavioral actions that help to look at life soberly, to find meaning in the most difficult trials, to solve any complex, sometimes extreme life and professional situations ${ }^{10}$. Note that the social position may be low, which the student occupies in relation to himself and other participants in the interaction. It is a kind of node of connections in social relations, and the role is the content of the requirements for a person who occupies a certain position in relation to the chosen profession. Thus, in the process of learning there is a gradual formation of the student not only as a professional, but also assertive personality, which is able to adapt to social interaction through the formed assertive behavior.

10 Лебедева И.Д. Психологические детерминанты ассертивности личности : автореф. дис. ... канд. психол. наук : 19.00.01. Красноярск, 2014. 23 с. 


\section{Modern educational and pedagogical strategies and technologies for the formation of assertive behavior of the student's personality}

The formation of the assertive personality of the student takes place in the educational environment, and the task of teachers is to create conditions where each student could express himself.

Such conditions represent a certain environment that combines a variety of opportunities and abilities of students, it is the ability to evaluate, build certain types of relationships to what is offered as the content of the education of assertive behavior ${ }^{11}$. Based on this, we can identify the most important and acceptable conditions of personalityoriented educational system, which will be focused on the successful development of assertive behavior of student youth. These are the following:

- creating an environment in the university that stimulates assertive behavior (the focus of educational activities on the creation of spiritual and subject space necessary for self-development, self-realization and self-determination of students, taking into account the influence of dominant factors in student life);

- pedagogical support of stimulating assertiveness in the process of communication and interaction (formation of such personal relationships and creation of such psychological climate which would promote free manifestation of initiative of student's youth, formation of interpersonal relationships on the basis of adequate mutual understanding and mutual respect);

- orientation of the educational process on a personality-oriented approach (organization of the educational system of the university on the basis of personality-oriented technologies, which, in turn, is a factor in its own development and a necessary condition for modeling and implementing educational technologies that contribute to youth needs values, free development of personality, formation of relations to oneself, to the world, development of self-consciousness of personality, help in its self-affirmation). Thus, the stimulation of self-development is the main tool of pedagogical and scientific influence of the university system on the student's consciousness in the process of development of assertive psychological qualities. In this process, the assertive approach

11 Эррера Л.М. Стимулирование социализации студенческой молодежи в социокультурной образовательной среде (личностно-ориентированный подход. Современные исследования сочиальных проблем. 2011. Т. 8. № 4. С. 55-64. 
most accurately reflects the democratic tendencies that must be manifested in educational activities.

In the opinion of L.M. Herrera, the introduction of specially modeled personality-oriented technologies of assertiveness formation in the university educational system should not only promote the development of interests and abilities of a young person, his personal growth, but also his self-knowledge, ability to reflect, his self-realization and selfactualization, his individual personality. development, ie to promote the process of socialization of student youth. The element of acculturation is becoming predominant in modern educational and pedagogical strategies and technologies. Modification of curricula involves the development of assertiveness, which is implemented in a block-modular approach. The programs contain modules: philosophical, sociological, economic, legal, political science with the inclusion in their content of a number of topics and issues in such subjects as psychology, management psychology, social psychology, educational psychology, culturology, business ethics, ethics and professional psychology activities, etc. In addition, the courses of the disciplines "Psychology", "Psychology of Communication" in the field of "Pharmacy" and "Psychology" and "Social Psychology" in the field of "Primary Education" at the National University (Uzhgorod) master the techniques and techniques of effective communication, including techniques of confrontation manipulation in communication, development of techniques for establishing contact and active listening, ways to resolve conflicts, assertive behavior in self-presentation training. The block-modular approach provides an opportunity to reorient the acquired knowledge to the future sphere of professional activity while increasing the level of socio-professional competence on the basis of the personal composition of social-value relations. It should be noted that higher education institutions demonstrate an unconventional approach to the study of assertiveness. Thus, an example is the teaching of disciplines "Psychology of Gender" in the field of "Psychology" and "Genderology and Feminology" in the field of "Social Work", where assertiveness is associated with the existence of a gender stereotype and, in addition to studying the topic of assertive behavior, the importance of assertiveness for modern women in our country and in the West. Also, the study of assertiveness is included in the courses of variable disciplines "Organizational Psychology" in terms of "Adaptation of employees in the organization", "Value regulation of the behavior of staff", "Loyalty and devotion to staff" and "Conflicts in the organization" in the field of "Chemistry". The implementation of innovative methods determines the 
joint creativity of teacher and student, a close connection with the future practical activities of students. For the formation of assertive behavior it is important to model the conditions that allow to develop selfconfidence skills, the ability to openly express positive and negative emotions, manage them, show respect for others and initiative (ability to offer and ask while maintaining self-worth), self-defense ability to say "no"). Since assertive behavior is manifested in interaction with others, it is important to form it in a group form of work (such as psychotraining or psychotherapy), which, if necessary, can be supplemented by individual forms.

The formation of the desired behavior can be carried out in the form of active social learning of adaptive behavioral responses. When conducting behavioral assessment, a deficit of leading social skills is often found. Students do not know how to listen to the interlocutor, provide feedback and self-disclosure, demonstrate confidence, resolve conflicts, resist negative environmental influences or make decisions. This method can take the form of training. In the first stages of work, areas in which students experience difficulties are identified, and motivation to learn is stimulated. Next, the types of desired behavior that are most appropriate in problematic situations are determined. Then students are given the opportunity to train in response to certain situations in the process of role play (psychologist, as a rule, plays the role of "opponent"). Finally, students are encouraged to apply rehearsal behaviors in real-life situations, endorsing them if successful, and supporting adaptive behaviors. The assertiveness training program contains three parts, the first of which is to form students' ideas about their own personal rights as professionals. Within this part of psychotraining we offer:

a) to acquaint students with the essence of assertive behavior and its significance for the future specialist;

b) provide information on human rights as individuals.

To implement these tasks, we consider it appropriate to use:

- case method, in which the analysis of professional situations provides students with tasks: read / listen to cases from practice and answer the following questions: What do you think they should do in these situations?, Why exactly?, What does a specialist need to be able to do as you suggest? (What personal quality is needed for this?);

- mini-lecture on the essence of assertive behavior, which provides group members with information about assertiveness as a personal quality. At the end of the lecture, questions are offered for discussion: 
Have you ever dealt with assertive personalities?, Describe cases of interaction with them, How did you interact with an assertive person?, How can you behave as an assertive person?

- discussion of assertiveness as a professionally important quality of the future specialist. Addressing the situations analyzed above, the questions are asked in practice: What could be the consequences of other behavior?. Ask participants to give examples of cases in their lives when they have shown non-assertive behavior, how they felt, what the consequences were. It is important to focus students' attention on the importance of assertiveness in future work.

- self-analysis of the degree of self-assertiveness, where participants are invited to analyze their own assertiveness. To do this, they need to remember and make a list of situations that happened to them in the last 2-3 years, in which it was difficult for them to defend their rights (they silently agreed with everything, or vice versa - reacted aggressively). These lists are then analyzed - in what types of situations or interactions with which people it is difficult for the student to be assertive (this may be a typical situation or interaction only with a certain category of people - say, on whom he depends, or inability to be assertive range of situations and does not depend on those with whom he interacts). The results of such an analysis are discussed in the group. Each of the participants chooses from his list 1-2 situations that are lost in the group, and it is important that the author of the situation was both in the role of himself and in the role of his "counterpart". The role play is played out according to the scenario described by the student. Next, be sure to discuss the following questions: How did you feel in that situation (when you played yourself)?, How did you really want to behave?, What prevented you from saying what you really wanted?, What did you do? did you feel when you played your opponent?

After each situation, a discussion is held with the group: How could you react in this case differently, so as to defend their rights and not violate the rights of their interlocutor? The same situations are played out according to the new scenario. In this case, the role of the author of the situation can be played by himself or by someone else from the group. It is important to ask the student how he or she feels about the new behavior.

- acquaintance with human rights, which strengthens its assertiveness. Here the participants are informed that the quintessence of the doctrine of assertiveness is the so-called assertive human rights. The list of such rights should be made in writing and placed on a flipchart. 
When reading the assertive rights of the individual, it is advisable to acquaint the participants with the beliefs of people that hinder the development of assertive behavior and incline it to a passive model of response. It should be noted that, on the one hand, these rights allow a person to be independent, but, on the other hand, by taking them to extremes - can lead to a pronounced individualism and ignoring the interests of others. Therefore, it is important to balance your interests with the interests of others, without ignoring them.

The second part of the training is to teach to distinguish between manifestations of assertiveness:

a) insufficient or excessive manifestations in professional communication situations;

b) role play - acting out situations of future professional activity. The group is offered several situations from professional activity, the situations themselves are described on separate sheets. Students form pairs: each of them performs their role and plays it. In the future, participants exchange pairs and roles, get new tasks - situations to play; analyze the level of assertiveness of participants in the played game situations; Feedback. Upon completion of the play of the proposed situations, a discussion is held;

c) analysis of cause-and-effect relations in played situations, discussion of role behavior of participants is carried out;

d) reflection of one's own experience of participation in a role play, it is suggested to make a generalization of the experience gained during the acting out of situations.

The third part of the formation of verbal and nonverbal skills: the ability to formulate requests, make demands, express positive and negative emotions, say "no", support and end the conversation.

It should be noted that within each part of the presented training the following techniques were used:

- open and covert modeling of specific situations of professional practice of a psychologist, which can provoke non-assertive or aggressive behavior of a specialist;

- instructing participants about the types of behavior in simulated situations and their possible consequences;

- working out of new behavioral reactions in role play, special exercises;

- consolidation of new behavioral reactions through feedback from the facilitator and other group members; 
- working out (analysis) of irrational ideas that prevent the formation of assertive behavior;

- providing information on human rights, which enhances the assertiveness of the individual;

- approbation of new (assertive) behavior in real situations;

- encouraging the spread of assertive behavior to new situations.

It should be noted that at the beginning of training sessions aimed at developing assertive skills, it is important to emphasize students' attention to the fact that the technique of assertive behavior is relevant in all spheres of life: in communication with friends, parents, co-workers, partners and even children. The basis of such behavior is the ability to show polite persistence in defending their interests, while maintaining a sense of self-worth and attention to the position of the interlocutor.

For some students who have persistent difficulties in developing assertive behavior skills, individual psychological counseling is offered (if these difficulties are related only to certain situations), or individual psychotherapy (if the difficulties are generalized and relate to many situations or situations of a certain type, require more in-depth training). It is worth noting that assertiveness training can be used in the form of individual, group work or in the form of self-help. Groups can be heterogeneous (for example, a group of individuals without problem behavior and with delinquent behavior) or homogeneous. The experience gained in specially organized student groups for the development of assertiveness, counteracts alienation, helps to solve problems in the field of interpersonal interaction in social relations in the future. In group training, participants have the opportunity to establish feedback and receive support from people who have common problems or experiences. In the process of group interaction a person learns to: take into account the needs, motives, values, personal qualities of others; understand the importance of having a sense of being accepted by others; appreciate their trust. Thus, thanks to the training program, movement is carried out together with the person, next to him, timely indication of possible means, as well as help and support if necessary; personal and professional formations related to the formation of assertive behavior of the student's personality in his professional development are developed and corrected.

Along with assertiveness training, other technologies are used to expand the positive behavioral repertoire of the individual. These are trainings of confidence, communication skills, decision-making, 
resistance to social pressure, conflict resolution. It uses a variety of techniques - role-playing games and game exercises, training in everyday situations, model training, positive reinforcement, video equipment, group discussions, methods of self-control, etc. ${ }^{12}$

Thus, modern technologies for the formation of assertive behavior of students in their professional development is an important tool of a comprehensive program aimed at improving personal competence, improving communication skills and self-presentation, education of selfconfidence. In the process, students learn about possible alternative behaviors, ways to deal with everyday stress, find the opportunity to reduce dependence on the opinions of others, learn to make decisions and be responsible for them, improve communication skills and receive incentives for self-development. Formation of assertive behavior is a creative, multifaceted process.

First, the individual needs to understand themselves (so that the individual realizes how much his behavior is determined by his own preferences and incentives and how - past experience (active negative early experience, lack / lack of positive experience, instilled attitudes).

Second - to form a style of assertive behavior. The main goals of the development of assertive behavior are realized through certain social situations that are formed in a role-playing game or real conditions.

Third - to master a certain amount of psychological knowledge and social competencies.

\section{CONCLUSIONS}

According to the results of the theoretical analysis of the development of assertiveness of students in their professional development, we note that:

1. Assertive behavior is understood as self-affirming activity, which is expressed, first of all, in independence, independence from others, in the ability to defend their rights and opinions with self-esteem and respect for others. In the professional development of future professionals, the main place should be given to the formation of assertive behavior through the development of confidence, motivation, volitional self-control, reducing anxiety and promoting a socially positive attitude in interaction in the student group. Due to assertive

12 Філоненко Л.А. Психологічні аспекти корекції соціальної спрямованості дезадаптованих підлітків. Збірник наукових праць Інституту психології імені Г.С.Костюка НАПНУ. Проблеми загальної та педагогічної психології. 2011. T. XIII. Ч. 5. C. 453-465. 
behavior, the future specialist has the following professionally important qualities: the ability to self-regulate their own behavior, independence from external influences and assessments; knowledge of one's rights and responsibilities; adequate assessment of yourself and others; awareness of personal needs and interests; understanding of own goals, intentions and ways of further actions provided to declare it openly and without discomfort; respect for the rights and interests of others; the ability to achieve goals without manipulating others; ability to persuade, win affection, seek advice or help from other participants in interpersonal interaction; ability to make compromise decisions; establish business contacts and partnerships, etc.

2. Assertiveness is a necessary quality of a modern competitive specialist and a condition for successful social contacts, so the implementation of assertiveness training programs, both social and professional in a block-modular approach, which allows to reorient the acquired knowledge to the future field of professional activity, should be given much attention.

3. The current state of development of assertiveness by didactic methods in domestic education occurs in the context of formation of professionally important qualities, which is especially important for groups of professions of the category "person - person", associated with such qualities as competence, ability to continuous professional growth. professional activity takes place in the mode of intensive social communications.

4. Implementation of a training program for the formation of assertive behavior of students in the process of their professional development, which is aimed at: 1) the formation of ideas of future professionals about their personal rights and responsibilities; 2) learning to distinguish between manifestations of assertiveness (insufficient or excessive manifestation in professional communication situations); 3) the development of self-confidence, the ability to openly express their thoughts, respecting the views of others; identify positive and negative emotions, manage them; take the initiative, offer and ask, while maintaining one's dignity, etc.

These conclusions do not cover all aspects of the problem under study. Prospects for further research, in our opinion, are to supplement the short list of areas that implement assertiveness training programs, including legal, medical, service disciplines. Within the framework of these disciplines to study assertiveness as a professionally important quality of a specialist in the relevant field, the formation of which is 
determined by the predominance of a set of selected educational technologies in terms of practice-oriented learning.

\section{SUMMARY}

The article is aimed at studying the social features of the development of assertive behavior of student youth. The relevance of the research topic is due to socio-political and socio-economic changes taking place in Ukraine, which in turn lead to significant changes in the behavior of young people. These changes actualize the process of finding the young generation of their own behavior, which would best meet their visions and desires, and, at the same time, the implementation of which would allow in the future to take a worthy place in society. As a result, there are contradictions between the conscious level of personal development and that which, in his own opinion, should be achieved. It is emphasized that the resolution of this contradiction occurs only when the individual is confident, has critical and creative thinking, firmly believes in their beliefs, is able to set goals and achieve them, which gives a qualitatively new level of development of the subject.

In the article, assertive behavior is considered as a self-affirming activity, which is expressed primarily in independence, independence from others, in the ability to defend their rights and opinions with selfrespect and respect for others. In particular, this behavior is characterized by conscious, confident behavior, based on informed and adequate decisions, which are the product of awareness of responsibility. A person who behaves assertively has a positive attitude towards other people, is able to listen to them, compromise, is able to change their own point of view under the influence of arguments.

It was found that in the learning process there is a gradual formation of the student not only as a professional but also assertive personality,

It is concluded that it is necessary to develop courses of assertiveness, the program of which should include the establishment of constructive communication links, behavioral flexibility, instilling skills in the use of communication algorithms.

\section{References}

1. Зеер Э.Ф. Психология профессионального образования : учебное пособие. Воронеж : Изд-во НПО «Модек», 2003. 480 с.

2. Дріга Т.Г. Психологічні особливості формування асертивності студентів вищого навчального закладу. Теоретичні $i$ прикладні проблеми психології. 2012. № 3 (29). С. 118-124. 
3. Семиченко В.А. Психологія особистості. Київ, 2001. 427 с.

4. Абрамова Г.С. Возрастная психология. Екатеринбург, 1999. $672 \mathrm{c}$.

5. Борисова А.А. Проницательность как проблема психологии общения. Вопросы психологии. 1990. № 4. С. 117-130.

6. Шамиева В.А. Ассертивность в стуктуре личности субъекта адаптации : автореф. дисс. ... канд. психол. наук : 19.00.01. Хабаровск, 2009. 27 с.

7. Лисовский В.Т. Советское студенчество: Социологические очерки. Москва, 1990. 304 с.

8. Пилипенко О.I. Удосконалення педагогічної соціалізації на основі асертивного підходу. Педагогічна теорія і практика. 2010. Вип. 3. С. 34-40.

9. Подоляк Н.М. Психологічні особливості асертивності. Наука i освіта. 2010. № 9. С. 108-111.

10. Лебедева И.Д. Психологические детерминанты ассертивности личности : автореф. дис. ... канд. психол. наук : 19.00.01. Красноярск, 2014. 23 с.

11.Эррера Л.М. Стимулирование социализации студенческой молодежи в социокультурной образовательной среде (личностноориентированный подход. Современные исследования соичильных проблем. 2011. Т. 8. № 4 . С. 55-64.

12. Філоненко Л.А. Психологічні аспекти корекції соціальної спрямованості дезадаптованих підлітків. Збірник наукових праць Інституту психології імені Г.С. Костюка НАПНУ. Проблеми загальної та педагогічної психологї. 2011. Т. ХІІІ. Ч. 5. С. 453-465.

\section{Information about the author:} Marchuk L. M.,

Candidate of Psychology, Associate Professor, Associate Professor at the General Pedagogy and Pedagogy of the Higher School Department Uzhhorod National University 14, Universitetska str., Uzhhorod, 88000, Ukraine 